\title{
Credit Assessment in Determining The Feasibility of Debtors Using Profile Matching
}

\author{
Husni Muharram Ritonga ${ }^{1}$, Hasrul Azwar Hasibuan ${ }^{2}$, \\ Andysah Putera Utama Siahaan ${ }^{3}$ \\ ${ }^{1,2}$ Faculty of Economics and Business, ${ }^{3}$ Faculty of Computer Science Universitas Pembangunan Panca Budi \\ Jl. Jend. Gatot Subroto Km. 4,5 Sei Sikambing, 20122, Medan, Sumatera Utara, Indonesia
}

\begin{abstract}
Credit assessment is a method used by banks or other financial institutions that are useful to determine whether a prospective debtor is feasible or not get a loan. The way is to collect customer data taken from the application data customer lending other than by using a statistical program that contains a history of loan among other things on how the payment cycle is billing the customer, if the customer pays bills on time or not, how many credits are still in progress. This assessment helps the banks to analyze credit applications besides other qualitative factors. If the customer has a problem in the smooth payment, the information will be known by funders. Profile Matching is the decision support system method to rank the client feasibility. It can assess based on particular parameters given. There are several parameters to be considered. It helps banks or other financial agents to pass the client borrowing money.
\end{abstract}

Keywords: Financial, Creditor, Debtor, Profile Matching

\section{INTRODUCTION}

Bank is a business entity that collects funds from the public in deposits and distributes to the public in the credits. Speaking about the credit, can not be separated from the purpose of the banks themselves. The purpose of banks is lending to a third party, public or debtor. Although people became the main target, in this case, not all credit applications from prospective borrowers approved by the banks. Parties that determine whether or not credit is agreed is a credit analyst team. Prospective debtors may have experienced rejection in the credit application. Why is the credit application rejected when banks had qualified it? Many factors go into a credit analyst before providing recommendations to agree or disagree to the debtor. They have filled the format and method in writing with the form, format, and the depth of the specified bank. Also, the analysis was not based on subjective considerations of the credit application.

Analysts have their way to provide an assessment of the feasibility to potential debtors. In the study, the author tries to give examples of credit ratings with the Profile Matching method. This method has the aspects and sub-aspects that have ratios respectively. Analysts can set the level comparison in every aspect. This method gives a great influence to the admissibility of an application for credit. On a monthly basis, there are many applications in creditors but not every application will be approved. This method aims to select some of all entries in the given period. Bank expects that this method has a good contribution in choosing which candidates are eligible to get a loan. By applying this method, an error in selecting consumer and bad credit could be avoided.

\subsection{Credit}

\section{THEORIES}

The term credit comes from the Italian word "credare". It means "trust," is the confidence of the lender (creditor) that the borrower (debtor) will recover the funds borrowed and interest thereon by the agreement going on between the two sides [1]. A creditor will trust the debtors that they will not be bogged down in the refund loans. Based on the Banking Law of the Republic of Indonesia Number 7 of 1992 that credit is the provision of money under contracts or the borrowing and lending between banks and other parties who require the borrower to repay the debt after a certain period with the amount of interest remuneration or profit sharing. The existence of credit in the economy affair is already used since a long time ago. It is often heard or even directly related to the credit in everyday life. The term loan is to be things that often we encounter in society. The easiest example is an electronics store, where many of its products are sold not only by the cash purchase system but also with the credit. Creditor right is to obtain payment, or the debtor's obligation is to make payments at the time requested or in the future because of the delivery of money at present.

In the credit, there is the principle of trust and prudence. Indicators of these beliefs are based on moral beliefs, commercial, financial, and assurance. While confidence in the credit can be divided into two, pure and reserve trust. Pure trust is when lenders extend credit to the debtor based only on trust without any warranty of any kind [6][7]. For example, the debtor to borrow money from friends and was not accompanied by any 
collateral, only based on mutual trust. While the reserve trust, the lender providing credit or loans to borrowers not only by faith alone but accompanied by a collateral matter. In lending at banks that are taking precedence is collateral for the loan, so not only based on the principle of trust alone.

Humans require credit because humans have needs that sometimes must be purchased by installments. Human needs are varied by the dignity that is always rising, while the ability to achieve something is limited. This causes the human need assistance to meet the desires and ideals. To improve business or usability of goods, people need material assistance from creditors. Provision of credit facilities has several objectives that must not be separated from the mission of the company is established. Credit has several functions as follows:

1. Improve usability exchange

Credit can improve the usability of money. If the money just kept alone, it will not produce anything useful.

The money is to be useful to produce goods or services by credit recipients.

2. Improve traffic circulation of money.

In this case, the money given or distributed will circulate from one area to another so that a region strapped with obtaining credit this region will receive additional money from other areas.

3. Improve usability of goods.

Loans granted by the bank's money will be used by the debtor to process into useful items that are not useful or helpful.

4. Improve circulation of goods.

Credit can also add or facilitate the flow of goods from one area to another, so that the amount of goods circulating from one area to another or credit increases may also increase the amount outstanding.

5. Maintain economic stability

By providing credit, it can be considered as economic stability because of the presence of loans will increase the number of items required by the community. Then the credits can also help in exporting goods from domestic to overseas thus increase foreign exchange.

6. Rise excitement of trying

The recipient will be able to increase the credits of the excitement of trying, especially for the customers who have limited capital.

7. Improve distribution of income

The more loans, the better, especially regarding increasing revenue. If a credit is given to build the plant, then the plant would require a workforce so, it may reduce unemployment. Besides, for the surrounding community will also have to increase revenue such as kiosks or rent a house for rent or other services.

8. Improve international relations.

Regarding international loans will be able to increase mutual need between the recipient of the loan with the lender. Lending by other countries will enhance cooperation in other fields.

Credit has several elements. The elements contained in the provision of credit facilities are as follows:

1. Trust

Confidence is a belief against the lender for granted received back in the future according to the credit period. The Bank provides trust from underlying why a credit can be brave in the drizzle.

2. Agreement

Agreement in an agreement that each party signed the rights and obligations of each. Agreements are in a credit agreement and signed by both parties before the credit is disbursed.

3. Period

From the period that has been agreed on of lending by banks and credit repayment by the debtor.

4. Risks

In avoiding bad risks in the credit agreement, binding agreements have previously performed the guarantees that are charged to the debtor or borrower.

5. Achievement

Achievement is an object of interest on an agreed fee by the bank and the debtor.

\subsection{Profile Matching}

Profile matching is a method often used as a mechanism for decision-making by assuming that there is an ideal level of predictor variables that must be met by the subjects studied, instead of the minimum rate that must be met or passed [2..5]. Here are some steps and formulation of the calculation method of profile matching:

1. Weighting

This phase will be determined the weight value of each aspect of using weights gap. Gap is the difference between the value of the aspect and the target value. It can be obtained by this formula.

$$
\text { Gap }=\text { Aspect Value }- \text { Target Value }
$$


2. Core and Secondary Factor

This stage determines the weight value gap necessary criteria, each criterion grouped into two groups: core factor and the secondary factor.

a. Core Factor

Core factor is the aspect most needed. The formula below is to calculate the core factor.

$$
N C F=\frac{\sum_{i=1}^{n} N C}{\sum_{i=1}^{n} I C}
$$

$\begin{array}{lll}\text { NCF } & : & \text { Core Factor Value } \\ \text { NC } & : & \text { Total Weight Core Factor } \\ \text { IC } & : & \text { Total Item Core Factor }\end{array}$

b. Secondary Factor

Secondary factors are the items other than that of the core aspects of factors. The formula for calculating the secondary factor is as follows:

$$
N S F=\frac{\sum_{i=1}^{n} N S}{\sum_{i=1}^{n} I S}
$$

$$
\begin{array}{lll}
\text { NSF } & : & \text { Secondary Factor Value } \\
\text { NS } & : & \text { Total Weight Secondary Factor } \\
\text { IS } & : & \text { Total Item Secondary Factor }
\end{array}
$$

3. Total Value Calculation

From the core calculation factors and secondary factors of every aspect, and then calculated the total value of each aspect of the estimated effect on the performance of each profile. To calculate the total value of each aspect, the following formula is used.

$$
N=(X) \% N C F+(X) \% N S F
$$

$\begin{array}{lll}\mathrm{N} & : & \text { Total value of each aspect } \\ \mathrm{NCF} & : & \text { Average Core Factor } \\ \mathrm{NSF} & : & \text { Average Secondary Factor } \\ \mathrm{X} \% & : & \text { Percentage value is entered }\end{array}$

4. Ranking

The final result of the profile matching process is a ranking which refers to the calculation results shown by this formula:

$$
R=70 \%+30 \% N C F N S F
$$

$$
\begin{array}{lll}
\mathrm{R} & : & \text { Rank value } \\
\mathrm{NCF} & : & \text { Core Factor value } \\
\mathrm{NSF} & : & \text { Secondary Factor value }
\end{array}
$$

\subsection{Assessment Criteria}

\section{PROPOSED WORK}

Before a credit facility granted, the bank must be sure that the loans should be completely paid [8]. Confidence is gained from the study of credit before the credit was disbursed. Research of credit by banks can be done in various ways to gain the confidence of its customers, such as through a correct assessment procedure and earnest. In conducting the criteria and aspects assessments remain the same. Usually, the common criteria assessment should be made by banks to get customers who deserve to be given.

1. Character

The character is the nature or character of the individual. The nature or character of the person who will be given the credit really should be trusted. In this case, the bank believes is true that the prospective debtor has a good reputation, it always means keeping promises and not involved matters relating to crime, for example, a gambler, a drunkard, or a swindler. To be able to read the nature or character of prospective borrowers can be seen from the customer background, both the background and the work of a personal nature as a way of life or enslaving lifestyle, family situation, hobbies, and social life. 
2. Capacity

Capacity is an analysis to determine the ability of customers to pay for the credit. Banks should know with certainty on the ability of prospective borrowers by analyzing its business from time to time. Revenue increases are expected in the future are always able to make the repayment on credit. Meanwhile, when an estimated incapable, the bank may reject the request of prospective borrowers. The name of capability often is called capacity.

3. Capital

Capital is the condition of property owned by the company that managed the prospective borrowers. Banks must examine the debtor in addition to the amount of capital is also its structure. To see whether the effective use of capital, it can be seen from the financial statements presented by performing such measurements regarding liquidity and solvency, profitability and other sizes.

4. Condition

Financing provided also need to consider the economic conditions associated with the prospective customer's business prospects. Condition assessment and business fields financed should have good prospects, so the possibility of problematic loans is relatively small.

5. Behaviour

Behaviour is to assess the customer regarding personality every day and his personality in the past. Personality assessment also includes attitudes, emotions, behavior and actions of customers in the face of a problem and resolve it.

6. Party

The party is to classify customers into classifications or certain groups based capital, loyalty, and character so that customers can be categorized into specific groups and will get different credit facilities from banks.

7. Purpose

The purpose is the aim of the customer in taking credit, including credit desired types of customers. The purpose lines of credit can vary as needed. For example, whether for working capital, investment, consumption, productive and others.

8. Prospect

Prospect is assessing the customer's business in the future whether favorable or not, in other words, have a prospect or vice versa. It is important because if a credit facility financed without having prospects, not only banks but also the loss of customers.

9. Payment

Payment is a measure of how customers return the loans that have been taken or from any source of funds for repayment of credit. The more sources of income of the debtor, the better. So that if other businesses will cover one attempt losers.

10. Profitability

Profitability is to analyze how the client's ability to seek profit. Profitability measured from period to period, whether it will remain the same or will increase, especially with the extra credits that will be earned.

11. Protection

The goal is to keep the loans get guaranteed protection, so the loans completely safe. The protection provided by the debtor may be a guarantee of goods or people or insurance.

\subsection{Assessment Instrument}

The intended instrument is a device that meets the requirements, so it can be used as a tool to measure an object measuring or collecting data about a variable. In the field of research, the instrument is defined as a tool to collect data on the variables of research for research needs. In the economic field, the instrument used to measure the level of credit capacity; factors suspected to have a relationship or effect on credit quality. Table 1 shows the modeling of the instruments used.

Table 1 Assessment instrument

\begin{tabular}{|c|c|}
\hline Variable & Instrument \\
\hline \multirow[t]{4}{*}{ Ability } & (A) Character \\
\hline & (B) Capacity \\
\hline & (C) Capital \\
\hline & (D) Condition \\
\hline \multirow[t]{3}{*}{ Personality } & (E) Behaviour \\
\hline & (F) Party \\
\hline & (G) Purpose \\
\hline \multirow[t]{4}{*}{ Feasibility } & (H) Prospect \\
\hline & (I) Payment \\
\hline & (J) Profitability \\
\hline & (K) Protection \\
\hline
\end{tabular}


Table 2 Scoring system

\begin{tabular}{|l|l|}
\hline REMARK & SCORE \\
\hline Disagree & 1 \\
\hline Neutral & 2 \\
\hline Agree & 3 \\
\hline
\end{tabular}

Table 2 shows the scoring system using Likert scale. There are three options in answering the questionnaire. They are DISAGREE, NEUTRAL, and AGREE.

\section{EVALUATION}

This section is the test of the provided instrument obtained earlier. The assessment must be converted into the Likert scale from "1" to "3". For this test, there will be five debtors who have different parameters. Table 3 shows the debtors data in three categories.

Table 3 Scoring data

\begin{tabular}{|c|c|c|c|c|c|}
\hline \multirow{3}{*}{\multicolumn{2}{|c|}{ DEBTORS }} & \multicolumn{4}{|c|}{ ABILITY } \\
\hline & & $\mathbf{A}$ & B & $\mathbf{C}$ & D \\
\hline & & CF & SF & SF & CF \\
\hline 1 & DEBTOR 1 & 2 & 3 & 1 & 2 \\
\hline 2 & DEBTOR 2 & 3 & 2 & 1 & 2 \\
\hline 3 & DEBTOR 3 & 1 & 2 & 3 & 3 \\
\hline 4 & DEBTOR 4 & 2 & 3 & 1 & 3 \\
\hline 5 & DEBTOR 5 & 1 & 2 & 3 & 2 \\
\hline \multirow{3}{*}{\multicolumn{2}{|c|}{ DEBTORS }} & \multicolumn{3}{|c|}{ PERSONALITY } & \\
\hline & & $\mathbf{E}$ & $\mathbf{F}$ & G & \\
\hline & & CF & $\mathbf{C F}$ & SF & \\
\hline 1 & DEBTOR 1 & 3 & 2 & 1 & \\
\hline 2 & DEBTOR 2 & 1 & 2 & 2 & \\
\hline 3 & DEBTOR 3 & 1 & 3 & 3 & \\
\hline 4 & DEBTOR 4 & 2 & 2 & 2 & \\
\hline 5 & DEBTOR 5 & 1 & 2 & 1 & \\
\hline \multirow{3}{*}{\multicolumn{2}{|c|}{ DEBTORS }} & \multicolumn{4}{|c|}{ FEASIBILITY } \\
\hline & & $\mathrm{H}$ & I & $\mathbf{J}$ & $\mathbf{K}$ \\
\hline & & SF & SF & CF & CF \\
\hline 1 & DEBTOR 1 & 2 & 3 & 3 & 1 \\
\hline 2 & DEBTOR 2 & 2 & 2 & 3 & 1 \\
\hline 3 & DEBTOR 3 & 2 & 2 & 3 & 1 \\
\hline 4 & DEBTOR 4 & 2 & 3 & 3 & 1 \\
\hline 5 & DEBTOR 5 & 2 & 3 & 3 & 1 \\
\hline
\end{tabular}

Table 4 : Target Value

\begin{tabular}{|l|l|l|l|l|}
\hline & A & B & C & D \\
\cline { 2 - 4 } TARGET & 2 & 2 & 2 & 2 \\
\cline { 2 - 4 } & E & F & G & \\
\cline { 2 - 4 } & 1 & 1 & 1 & \\
\cline { 2 - 4 } & H & I & J & K \\
\cline { 2 - 4 } & 2 & 2 & 2 & 2 \\
\hline
\end{tabular}

Table 4 shows the target value of each parameter. Data is categorized into three aspects, Ability, Personality, and Feasibility. There area eleven parameters. Each of them is filled with the previous score and compared with the existing target value. Table 5 shows the gap value obtained. 
Table 5 Gap value

\begin{tabular}{|c|c|c|c|c|c|}
\hline \multirow{3}{*}{\multicolumn{2}{|c|}{ DEBTORS }} & \multicolumn{4}{|c|}{ ABILITY } \\
\hline & & \multirow{2}{*}{$\begin{array}{l}\mathrm{A} \\
\mathrm{CF}\end{array}$} & \multirow{2}{*}{$\begin{array}{l}\text { B } \\
\text { SF }\end{array}$} & \multirow{2}{*}{$\begin{array}{l}\mathrm{C} \\
\mathrm{SF}\end{array}$} & \multirow{2}{*}{$\frac{\mathrm{D}}{\mathrm{CF}}$} \\
\hline & & & & & \\
\hline 1 & DEBTOR 1 & 0 & 1 & -1 & 0 \\
\hline 2 & DEBTOR 2 & 1 & 0 & -1 & 0 \\
\hline 3 & DEBTOR 3 & -1 & 0 & 1 & 1 \\
\hline 4 & DEBTOR 4 & 0 & 1 & -1 & 1 \\
\hline 5 & DEBTOR 5 & -1 & 0 & 1 & 0 \\
\hline \multirow{3}{*}{\multicolumn{2}{|c|}{ DEBTORS }} & \multicolumn{3}{|c|}{ PERSONALITY } & \\
\hline & & $\mathbf{E}$ & F & G & \\
\hline & & $\mathrm{CF}$ & CF & SF & \\
\hline 1 & DEBTOR 1 & 2 & 1 & 0 & \\
\hline 2 & DEBTOR 2 & 0 & 1 & 1 & \\
\hline 3 & DEBTOR 3 & 0 & 2 & 2 & \\
\hline 4 & DEBTOR 4 & 1 & 1 & 1 & \\
\hline 5 & DEBTOR 5 & 0 & 1 & 0 & \\
\hline \multirow{3}{*}{\multicolumn{2}{|c|}{ DEBTORS }} & \multicolumn{4}{|c|}{ FEASIBILITY } \\
\hline & & H & I & $\mathbf{J}$ & $\mathbf{K}$ \\
\hline & & SF & SF & CF & $\mathrm{CF}$ \\
\hline 1 & DEBTOR 1 & 0 & 1 & 1 & -1 \\
\hline 2 & DEBTOR 2 & 0 & 0 & 1 & -1 \\
\hline 3 & DEBTOR 3 & 0 & 0 & 1 & -1 \\
\hline 4 & DEBTOR 4 & 0 & 1 & 1 & -1 \\
\hline 5 & DEBTOR 5 & 0 & 1 & 1 & -1 \\
\hline
\end{tabular}

After the gap values are retrieved, those values will be converted into Profile Matching rule using the gap rule as seen in Table 6. The Core and Secondary Factors are retrieved from the values by using the earlier formulas. It must have determined which are the core factors and secondary factors.

Table 6 Gap rule

\begin{tabular}{|l|l|}
\hline GAP & VALUE \\
\hline 0 & 4 \\
\hline 1 & 4,5 \\
\hline-1 & 3,5 \\
\hline 2 & 5 \\
\hline-2 & 3 \\
\hline
\end{tabular}

Table 7 Core Factor and Secondary Factor of Ability

\begin{tabular}{|c|c|l|l|l|l|l|l|}
\hline \multicolumn{2}{|l|}{ WEIGHT } & \multicolumn{3}{|l|}{ PERFORMANCE } & CF & SF \\
\hline 1 & DEBTOR 1 & 4,00 & 4,50 & 3,50 & 4,00 & 4,00 & 4,00 \\
\hline 2 & DEBTOR 2 & 4,50 & 4,00 & 3,50 & 4,00 & 4,25 & 3,75 \\
\hline 3 & DEBTOR 3 & 3,50 & 4,00 & 4,50 & 4,50 & 4,00 & 4,25 \\
\hline 4 & DEBTOR 4 & 4,00 & 4,50 & 3,50 & 4,50 & 4,25 & 4,00 \\
\hline 5 & DEBTOR 5 & 3,50 & 4,00 & 4,50 & 4,00 & 3,75 & 4,25 \\
\hline
\end{tabular}

Table 8 Core Factor and Secondary Factor of Personality

\begin{tabular}{|l|l|l|l|l|l|l|}
\hline \multicolumn{2}{|l|}{ WEIGHT } & \multicolumn{3}{|c|}{ MOTIVATION } & CF & SF \\
\hline 1 & DEBTOR 1 & 5,00 & 4,50 & 4,00 & 4,75 & 4,00 \\
\hline 2 & DEBTOR 2 & 4,00 & 4,50 & 4,50 & 4,25 & 4,50 \\
\hline 3 & DEBTOR 3 & 4,00 & 5,00 & 5,00 & 4,50 & 5,00 \\
\hline 4 & DEBTOR 4 & 4,50 & 4,50 & 4,50 & 4,50 & 4,50 \\
\hline 5 & DEBTOR 5 & 4,00 & 4,50 & 4,00 & 4,25 & 4,00 \\
\hline
\end{tabular}

Table 9 Core Factor and Secondary Factor of Feasibility

\begin{tabular}{|c|c|l|l|l|l|l|l|}
\hline \multicolumn{2}{|l|}{ WEIGHT } & \multicolumn{3}{|l|}{ JOB TRAINING } & CF & SF \\
\hline 1 & DEBTOR 1 & 4,00 & 4,50 & 4,50 & 3,50 & 4,00 & 4,25 \\
\hline 2 & DEBTOR 2 & 4,00 & 4,00 & 4,50 & 3,50 & 4,00 & 4,00 \\
\hline 3 & DEBTOR 3 & 4,00 & 4,00 & 4,50 & 3,50 & 4,00 & 4,00 \\
\hline 4 & DEBTOR 4 & 4,00 & 4,50 & 4,50 & 3,50 & 4,00 & 4,25 \\
\hline 5 & DEBTOR 5 & 4,00 & 4,50 & 4,50 & 3,50 & 4,00 & 4,25 \\
\hline
\end{tabular}


Table 7 to 9 are the calculation of all aspects. There are core and secondary factors inside. As the values are obtained, the average value of the ratio of 6:4 (adjustable) between the core and secondary factor is initiated. The following table shows the N1, N2 and N3 as the aspect values.

Table 10 Aspect Values

\begin{tabular}{|l|l|l|l|l|}
\hline \multicolumn{2}{|l|}{} & N1 & N2 & N3 \\
\hline 1 & DEBTOR 1 & 4,00 & 4,45 & 4,10 \\
\hline 2 & DEBTOR 2 & 4,05 & 4,35 & 4,00 \\
\hline 3 & DEBTOR 3 & 4,10 & 4,70 & 4,00 \\
\hline 4 & DEBTOR 4 & 4,15 & 4,50 & 4,10 \\
\hline 5 & DEBTOR 5 & 3,95 & 4,15 & 4,10 \\
\hline
\end{tabular}

The aspect ratio is $4: 2: 4$ (adjustable). The rank is calculated based on this ratio. The final score is the average of the N1, N2 and N3. Table 11 shows the final score of this case.

Table 11 Result of Final Score

\begin{tabular}{|l|l|l|l|l|l|}
\hline \multirow{2}{*}{\multicolumn{2}{|l|}{ RANKING }} & \multicolumn{3}{l|}{ VALUES } \\
\cline { 3 - 6 } & N1 & N2 & N3 & R \\
\hline 1 & DEBTOR 1 & 4,00 & 4,45 & 4,10 & 4,13 \\
\hline 2 & DEBTOR 2 & 4,05 & 4,35 & 4,00 & 4,09 \\
\hline 3 & DEBTOR 3 & 4,10 & 4,70 & 4,00 & 4,18 \\
\hline 4 & DEBTOR 4 & 4,15 & 4,50 & 4,10 & 4,20 \\
\hline 5 & DEBTOR 5 & 3,95 & 4,15 & 4,10 & 4,05 \\
\hline
\end{tabular}

Table 11 illustrates the results of the Profile Matching method. DEBTOR 4 gained the highest opportunity to get the loan. For example, if the bank let three applicants, DEBTOR 2 and DEBTOR 5 are not nominated.

\section{CONCLUSION}

Credit loans are very useful for the general public. However, there are some requirements that must be met for the loan successfully obtained. Profile Matching Method is a good technique to see who will qualify for the mortgage loan. This method can examine some aspects related to the debtor. Analysts can set the desired target value. The drawback of this system is the absence of tolerance humanly to consider a debtor to obtain a loan.

\section{REFERENCES}

[1]. Jogiyanto, Analisis dan Desain Sistem Informasi : Pendekatan Terstruktur, Teori dan Praktek Aplikasi Bisnis, vol. 23, Yogyakarta: Andi Offset, 2005, p. 107-115.

[2]. Z. Tharo and A. P. U. Siahaan, "Profile Matching in Solving Rank Problem," IOSR Journal of Electronics and Communication Engineering, vol. 11, no. 5, pp. 73-76, 2016.

[3]. A. P. U. Siahaan, "Fuzzification of College Adviser Proficiency Based on Specific Knowledge," International Journal of Advanced Research in Computer Science and Software Engineering, vol. 6, no. 7, pp. 164-168, 2016.

[4]. Kusrini, Konsep dan Aplikasi Sistem Pendukung Keputusan, Yogyakarta: Andi Offset, 2007.

[5]. D. J. Power, Decision Support Systems : Concepts and Resources For Manager, USA: Greenwood, 2002.

[6]. S. Leksono, "The Implementation of Kredit Usaha Rakyat Granting on Market Traders Who Are the Customers of Bank Rakyat Indonesia in Tawangalun Banyuwangi," Journal of Marketing and Consumer Research, vol. 19, no. 1, pp. 63-69, 2016.

[7]. $\quad$ "Usaha Mikro, Kecil, dan Menengah dan Bank," Undang-Undang Republik Indonesia, vol. 20, 2008.

[8]. H. A. Hasibuan, R. B. Purba and A. P. U. Siahaan, "Productivity Assessment (Performance, Motivation, and Job Training) Using Profile Matching," SSRG International Journal of Economics and Management Studies, vol. 3, no. 6, pp. 73-77, 2016. 